University of Warwick institutional repository: http://go.warwick.ac.uk/wrap

This paper is made available online in accordance with publisher policies. Please scroll down to view the document itself. Please refer to the repository record for this item and our policy information available from the repository home page for further information.

To see the final version of this paper please visit the publisher's website. Access to the published version may require a subscription.

Author(s): Steve Fuller

Article Title: History of science for its own sake?

Year of publication: 2010

Link to published article:

http://dx.doi.org/10.1177/0952695110372024

Publisher statement: (C) History of the Human Sciences; Sage

Publications Ltd. 


\section{History of Science for Its Own Sake?}

\section{Steve Fuller}

I see two major themes arising from Mark Erickson's (2010) provocative question, 'Why should I read histories of science?' The first pertains to the apparent failure of historians to address 'why' the history has taken the course it has. Although Erickson singles out histories written by professional scientists, it is a question that is also fairly asked of professional historians, who remain sufficiently turned against positivism to prefer microcontextualisations of the past. The second theme concerns the audience for histories of science. Here I am much less happy than Erickson with Shapin's (2005) characterisation of how historical writing about science would need to change in order to acquire a wider audience.

Even the most retrograde internalist account has a very clear sense of the line of causation that runs through the history of science, since the history itself unfolds a logic of increasing epistemic progress. This logic accounts for which details are included and excluded from the narrative that is presented as one insight building upon previous ones, all illuminating some domain of reality that is always coming clearer into view. Thus, one talks about only that which is essential to realizing the overall telos. In this respect, Agassi's (1963) term 'inductivist' is a bit deceptive because the term is really being used as a synonym for 'incremental' (as opposed to 'revolutionary') change, but not in its strict logical sense as the opposite of 'deductivist'. In fact, Agassi's so-called inductivist historians of science are in fact very deductivist insofar as they believe that there are foundational universal premises of theory and method that underwrite the entire scientific enterprise, and which the history comes gradually to discover. The history of science is a collective learning exercise by which humanity understands the nature of reality. Thus, the great positivist pioneers of the history of science discipline - both practising scientists like Ernst Mach and practising historians like George Sarton - made a point of addressing both colleagues and the general public in their historical works.

This whole way of thinking about the history of science, which owes more than a small debt to German idealism, was raised to a notoriously ironic level of self-consciousness in Imre Lakatos' historiography of science as 'rational reconstruction', according to which the actual historical details that deviate from the logical step-wise narrative are consigned to the footnotes (Lakatos 1978: chap. 2). This meant that often the footnotes were very lengthy and argumentative, as scientists whose word was gospel for many decades in their fields got portrayed as ignoramuses-in-the-making. Much of the moral fervour that informed the empiricist backlash of both naturalistic philosophers (e.g. Larry Laudan) and constructivist sociologists (e.g. David Bloor) of science starting in the late 1970s was fuelled by the perception that the Lakatosian vision was propelled by a science-worshipping philosophical arrogance that betrayed a casual disregard for the facts. At least, this appeared to be the mood of the history and philosophy of science departments where I was a graduate student in the early 1980s. A precedent for Lakatos -- and the contempt that his project generated -- might be theological defences of the divine right of kings based on Biblically 'rationalised' histories, outrage at which helped spark the $17^{\text {th }}$ century wars of religion in Europe.

However, with the coolness afforded by historical distance, I would argue that there is merit to what Lakatos was trying to do. Whatever his other faults, Lakatos - or the positivists who came before him - could not be accused of lacking a clear sense of the object of scientific 
inquiry. If nothing else, 'progress' presupposes a determinate origin and aim. To be sure, the identities of both ends of the process may be contested but that there are the two ends is not contested. If one takes such a view of the history of science seriously, then its facts come to be weighed in a particular way. Erickson observes that John Gribbin (2002), whom I take to be a vulgar positivist, makes several factual errors in his physics-led general history of science. While one might regret such errors and hope they are corrected in subsequent editions of the work, their epistemic significance needs to be measured by how much they impede the narrative logic that Gribbin wishes to advance. Assuming that Gribbin's view of the actual history of science is like Lakatos', such errors of fact may count as little more than typographical errors. In both cases they simply pertain to contingent features of the historical narrative that could have gone one way or another at a particular moment without affecting the truth of the overall trajectory.

But notice that to make this sort of judgement, one needs to have a reasonably clear sense of where the trajectory of science is heading - at least clear enough to distinguish what has been contingent and necessary to its development. While today's readers may regard this as an impossibly high epistemic standard, if it is not met, does the 'history of science' retain any proper meaning at all? To be sure, it is possible to do a history of the word 'science' and its various cognates. But given the word's clear normative import, that project would amount to tracking the descendants of Plato's interest in knowledge for statecraft (Fuller 1988: chap. 7). It would thus follow the history of politics a bit more closely than most professional scientists and historians of science would find comfortable, since much of what both groups want to talk about as 'science' originated in the margins of power and only fitfully made their way to the centres of epistemic authority. Of course, much of this discussion is obviated, as Erickson rightly points out, because at least professional historians have come to accept that social context is integral to understanding the history of science. But that now widely agreed practise threatens to turn the 'history of science' into a history of everything as seen through science, the comic potential of which Bill Bryson's (2004) best-selling book has already realized.

For at least the past quarter century, professional historians of science of my generation have found a diplomatic solution to the problem raised here. They have simply evacuated the concept of science of any univocal meaning. Their modus operandi is traceable to Foucault's (1970) archaeology of knowledge. In Foucault's wake, historians have acquired a sense of 'objectivity' that involves treating everything as remnants of societies long past to which they themselves do not belong. The historiographical significance of the object in this context is that, above all, an object is something that has clear boundaries - both spatial and temporal. Foucault himself turned this point to great effect in writing about 'man' as an object on the intellectual horizon that was formally launched at the end of the $18^{\text {th }}$ century but was gradually disappearing at the end of the $20^{\text {th }}$ century.

In a similar vein, while one might admire Peter Galison (1997) for his ability to write about the theory-experiment relationship with an attention to technical detail that merits praise from professional physicists, in the end he is discussing these matters as the outcomes of practises surrounding particular artefacts through which 'trading zones' have been managed for the transaction of information. It is as if Galison first dug up the original Monte Carlo simulators from the ground and then endeavoured to find a sympathetic interpretation of their purpose. Such a modus operandi is very much in the spirit of someone detached from any larger vision that might have been shared by the scientists directly involved in the enterprise. In fact, it might be seen as an exercise in giving those scientists a decent burial - that is, demonstrating 
respect for their project in terms they would have appreciated, while at the same admitting that the limit of their activities has been reached.

The 'new objectivism' that characterises so much of professional history of science today (e.g. Daston and Galison 2007) is arguably a half-hearted response to the breakdown of the modernist metanarrative. Because they largely accept the postmodernist premise that scientific progress is a failed myth, historians nowadays feel no obligation to participate in its perpetuation, and hence are no longer compelled to issue clear judgements about what does and does not matter to the advancement of science. This removes any need for the historian to have a recognisable personality that is ideologically invested in the metanarrative's outcome. Such a 'de-subjectivisation' of history is a potential impediment to directly addressing a broad audience. Here it is worth recalling that despite the difficulty, if not outright unreadability, of his works, Stephen Hawking's unique selling point as a popular science writer has been his ability to recount the history of physics as culminating in his own ongoing research. The persuasiveness of this subjective appeal, present to varying degrees in positivist popular histories, should never be underestimated. In its absence, history can easily dissolve into a mass of details, each of equal significance, but lacking any overall direction.

The solution to this problem sought by today's new objectivists is reminiscent of those Romantics and Victorians who turned to aestheticism ('art for art's sake') in the $19^{\text {th }}$ century to channel their residual religious sentiment in an increasingly secular world. The difference, of course, is that the sentiment now derives from a scientific source, typically physics. But in both cases, one focuses on particular objects as if they were ends in themselves - that is, not serving any larger purpose. The objects are presented as the culmination of various converging processes rather than as transitional stages through which these processes are working in order to achieve something greater in the future. Thus, Leonardo's The Last Supper or the Monte Carlo simulator might be presented as a site of multiple influences that are delicately negotiated in terms of the object's construction. This captures the iconographic standpoint favoured by the aesthete who has no instrumental interest in the object, which by definition has already done all that it could do. However, those who see the object as a moment in a living enterprise would want to make judgements about what is worth preserving, removing and enhancing in future versions. Such is the standpoint of people actively engaged in the project that produced the object. It is how both artists and scientists tend to treat their own past. They personalise their interactions with the object, so that its value is carried over in their own activity and its products.

For what it is worth, aestheticism can be credited with demonstrating that subjective involvement is not the only way to make an extraordinary human activity appear valuable. And just as one can appreciate art without being an artist, one can appreciate science without being a scientist. The latter is certainly implicit in the new objectivism and comes out clearly in Erickson's quote from Shapin (2005). In both cases, the process is cast as highbrow entertainment: a self-consuming activity aimed at a self-contained object. In this respect, Shapin's 'cocktail party' standard of historiographical relevance might be seen as a latter-day version of Aristotle's principles of good theatre. However, someone more cynical than I might observe that such entertainment functions as a disincentive to follow in the footsteps of the original artists and scientists whose work is depicted, except in the manner of a wake.

In any case, it would be a mistake to conclude that aestheticism is the only, let alone the best, route for popular science written by those not active in science's own front lines. In fact, the dominant mode of popular science writing in the first half of the $20^{\text {th }}$ century was a kind of 
advocacy journalism that leveraged contemporary developments into visions of future utopias. Exemplary works in this vein were penned by HG Wells and JG Crowther in Britain, as well as by the first dedicated science columnist in a US newspaper, Waldemar Kaempffert of The New York Times. Spiritual descendants of these figures are conspicuous by their absence today, their numbers already beginning to decline once we entered the 'Atomic Age'. However, the reason for this decline is hardly mysterious. Between them, the three figures I mentioned gave ideological forward momentum to much of what turned out to be the most destructive and authoritarian tendencies in the century's history, including Fascism and Communism. So, while I would personally welcome a revival of a more utopian and futuristic approach to popular science as an antidote to the aestheticism favoured by today's historians of science, aestheticism does enjoy the virtue of being harmless.

\section{References}

Agassi, J. (1963). Towards an historiography of science. The Hague: Mouton Bryson, B. (2004). A Short History of Nearly Everything. London: Black Swan. Daston, L. and P. Galison (2007). Objectivity. Cambridge MA: MIT Press. Erickson, M. (2010). 'Why should I read histories of science?' History of the Human Sciences...

Foucault, M. (1970). The Order of Things (Orig. 1966). New York: Random House. Fuller, S. (1988). Social Epistemology. Bloomington IN: Indiana University Press. Galison, P. (1997). Image and logic: a material culture of microphysics. Chicago: University of Chicago Press.

Gribbin, J. (2002). Science: a history 1543-2001. London: Penguin.

Lakatos, I. (1978). Methodology of Scientific Research Programmes. Cambridge UK: Cambridge University Press.

Shapin, S. (2005). 'Hyperprofessionalism and the crisis of readership in the history of science'. Isis 96(2): 238-243. 